\title{
Tetanus-CMV Fusion Peptide Vaccine
}

National Cancer Institute

\section{Source}

National Cancer Institute. Tetanus-CMV Fusion Peptide Vaccine. NCI Thesaurus. Code C78821.

A vaccine containing an inactivated epitope of tetanus toxin fused to a cytomegalovirus (CMV) peptide epitope, with potential anti-viral and immunomodulating activities. Upon administration, tetanus-CMV fusion peptide may stimulate a cytotoxic T-lymphocyte $(\mathrm{CTL})$ response ag ainst $\mathrm{CMV}$ in the $\mathrm{CMV}$-infected host. T etanus toxin contains universal T cell helper epitopes. 